\title{
Erratum to: Pre and Post Operative 3D Echocardiographic Appearance of Isolated Cleft of the Anterior Mitral Valve Leaflet
}

Meive Furtado - Jose Andrade - Edmar Atik •

Roberto Kalil-Filho

Published online: 2 April 2010

(C) Springer Science+Business Media, LLC 2010

Erratum to: Pediatr Cardiol

DOI 10.1007/s00246-010-9676-y

Unfortunately there was a typo in the article title. The sixth word in the title should be 'Echocardiographic' instead of 'Ecocardiographic'.

The online version of the original article can be found under doi:10.1007/s00246-010-9676-y.

M. Furtado $(\bowtie) \cdot$ J. Andrade $\cdot$ E. Atik · R. Kalil-Filho

Department of Echocardiography, Hospital Sírio-Libanês,

São Paulo, Brazil

e-mail: meivefurtado@hotmail.com 